\section{\#089 Os efeitos do tratamento ortodôntico na posição do osso hioide: um estudo retrospetivo}

Inês Ferreira de Oliveira, Mariana Gonçalves, Sérgio Neto, Elsa Rodrigues Carvalho, Maria João Ponces*

Faculdade de Medicina Dentária da Universidade do Porto - FMDUP; Escola Superior do Vale do Sousa

Objetivos: Analisar a posição do osso hióide em relação às estruturas adjacentes numa população ortodôntica através da avaliação de telerradiografias faciais em incidência de perfil antes e após o tratamento ortodôntico recorrendo ao método do Triângulo Hioide, proposto por Bibby em 1981 e Rocabado em 1983. Materiais e métodos: Foram analisadas as telerradiografias de T0 (antes) e T1 (após o tratamento ortodôntico) de 158 indivíduos (69 do género masculino e 89 do feminino) tratados no Departamento de Ortodontia da Faculdade de Medicina Dentária da Universidade do Porto. O triângulo hioideu (C3-RGn, C3-H, H-RGn) foi estudado nos subgrupos criados em função das classes esqueléticas e dentárias através da análise realizada no Software Image ${ }^{\circledR}$. O tratamento estatístico foi realizado com o software SPSS ${ }^{\circledR}$ utilizando teste T-student e análises de variância, considerando um nível de significância de $5 \%$ ( $p<0.05)$. Resultados: O aumento da distância C3-RGn foi estatisticamente significativo em pacientes com Classe II divisão 1 e com Classe II esquelética. O aumento da distância C3-H foi estatisticamente significativo em todos as Classes dentárias e esqueléticas, exceto em pacientes com Classe III dentária e esquelética. Em relação à distância H-RGn, H-H' e o ângulo HP não foram encontradas diferenças de T0 para T1. Conclusões: Considerando a sua relação bidimensional, o osso hióide adotou uma posição mais anterior em relação à cervical (exceto na Classe III dentária e esquelética) mas a sua relação com a mandíbula não sofreu alterações estatisticamente significativas.

http://doi.org/10.24873/j.rpemd.2020.12.812
\#090 Distração osteogénica dento-ancorada: análise radiológica de dois protocolos de ativação

Francisco Vale, Raquel Travassos*, José Pedro Figueiredo, Inês Francisco

Centro Hospitalar e Universitário de Coimbra; Instituto de Ortodontia - Faculdade de Medicina da Universidade de Coimbra

Objetivos: Avaliar radiologicamente dois protocolos de ativação da distração osteogénica dento-ancorada no alongamento sagital mandibular canino. Materiais e métodos: 7 cães Beagle, com peso entre os $15-18 \mathrm{Kg}$ foram submetidos a distração osteogénica e 3 permaneceram como grupo controlo. Ambas as hemimandíbulas foram utilizadas, formando os grupos experimentais: A: 6 hemimandíbulas - grupo controlo; B: 7 hemimandíbulas -ativações bidiárias de 0,5 mm; C: 7 hemimandíbulas - ativação diária de $1 \mathrm{~mm}$. Após a distracção seguiu-se um período de consolidação de 12 semanas. Semanalmente foi realizada a avaliação da regeneração óssea no espaço de distração através de radiografias de incidência oclusal. Resultados: Durante os dez dias de ativação, verificou-se o deslocamento sagital gradual com sentido póstero-anterior dos fragmentos mandibulares, anteriores à osteotomia. Nas primeiras quatro semanas de consolidação, observaram-se pequenos focos retangulares radiopacos com orientação paralela ao eixo de distração em todas as hemimandíbulas dos grupos B e C. No decurso deste período, verificou-se uma radiopacidade crescente até à décima segunda semana, na qual se observou uma zona uniforme de mineralização em todas as hemimandíbulas. Conclusões: O protocolo de distração, através do dispositivo dento-ancorado, é eficaz no alongamento sagital mandibular. A distração possibilitou uma formação óssea semelhante à arquitetura óssea original, sobretudo no grupo de distração bidiária.

http://doi.org/10.24873/j.rpemd.2020.12.813 